\title{
Socio-Environmental Health Analysis in Nogales, Sonora, Mexico
}

\author{
Laura M. Norman · Felipe Caldeira $\cdot$ James Callegary · \\ Floyd Gray • Mary Kay O' Rourke • \\ Veronica Meranza $\cdot$ Saskia Van Rijn
}

Received: 27 October 2011 / Revised: 15 March 2012 / Accepted: 17 March 2012 / Published online: 12 April 2012

(C) Springer Science+Business Media B.V. (outside the USA) 2012

\begin{abstract}
In Nogales, Sonora, Mexico, some neighborhoods, or colonias, have intermittent delivery of water through pipes from the city of Nogales's municipal waterdelivery system while other areas lack piped water and rely on water delivered by truck or pipas. This research examined how lifestyles, water quality, and potential disease response, such as diarrhea, differs seasonally from a colonia with access to piped water as opposed to one using alternative water-delivery systems. Water samples were collected from taps or spigots at homes in two Nogales colonias. One colonia reflected high socio-environmental conditions where residents are supplied with municipal piped water (Colonia Lomas de Fatima); the second colonia reflected low socio-environmental conditions, lacking access to piped water and served by pipas (Colonia Luis Donaldo Colosio). A survey was developed and implemented to characterize perceptions of water quality, health impacts, and quality of life. Water samples were analyzed for microbial and inorganic water-quality parameters known to impact human health including, Escherichia coli (E. coli), total coliform bacteria, arsenic, and lead. A total of 21 households agreed to participate in the study (14 in Colosio and 7 in Fatima). In
\end{abstract}

L.M. Norman $(\varangle) \cdot$ F. Caldeira · J. Callegary · F. Gray

U.S. Geological Survey, Border Environmental Health Initiative (BEHI), 520 N. Park Avenue, Tucson, AZ, USA

e-mail: lnorman@usgs.gov

F. Caldeira · M.K. O’ Rourke · S. Van Rijn

Mel and Enid Zuckerman College of Public Health (MEZCOPH),

University of Arizona, Tucson, AZ, USA

V. Meranza

Municipal Operating Agency for Water and Wastewater (el Organismo Operador Municipal de Agua Potable Alcantarillado y Saneamiento; OOMAPAS), Nogales, Sonora, Mexico both colonias metal concentrations from water samples were all well below the United States Environmental Protection Agency's (US EPA's) maximum contaminant levels. E. coli concentrations exceeded the US EPA's drinking-water standard in Colosio but not Fatima. Total coliform bacteria were present in over $50 \%$ of households in both colonias. Microbial contamination was significantly higher in the summer than in the winter in both colonias. Resulting analysis suggests that residents in colonias without piped water are at a greater risk of gastrointestinal illness from consumption of compromised drinking water. Our survey corroborated reports of gastrointestinal illness in the summer months but not in the winter. Chloride was found to be significantly greater in Colosio (median $29.2 \mathrm{mg} / \mathrm{L}$ ) although still below the US EPA's maximum contaminant levels of $250 \mathrm{mg} / \mathrm{L}$. Ongoing binational collaboration can promote mechanisms to improve water quality in cities located in the US-Mexico border.

Keywords Water quality $\cdot$ Microbial analysis $\cdot$ Metal analysis · Quality of life · Environmental health ·

US-Mexico border

\section{Introduction}

People become more susceptible to health problems when exposed to contaminated water, including infectious intestinal diseases. The impacts and risk perceptions of environmental health are not well understood in the developing world where waterborne disease is a major problem (Morua et al. 2011). Deficiencies in water management and inequities in water consumption in Mexico make the low-income groups particularly susceptible to disparities in water access (Brans 1997). The US-Mexico border zone 
Fig. 1 Location map of Nogales, Sonora-display access to piped water Nogales-outlining Fatima and Colosio study areas

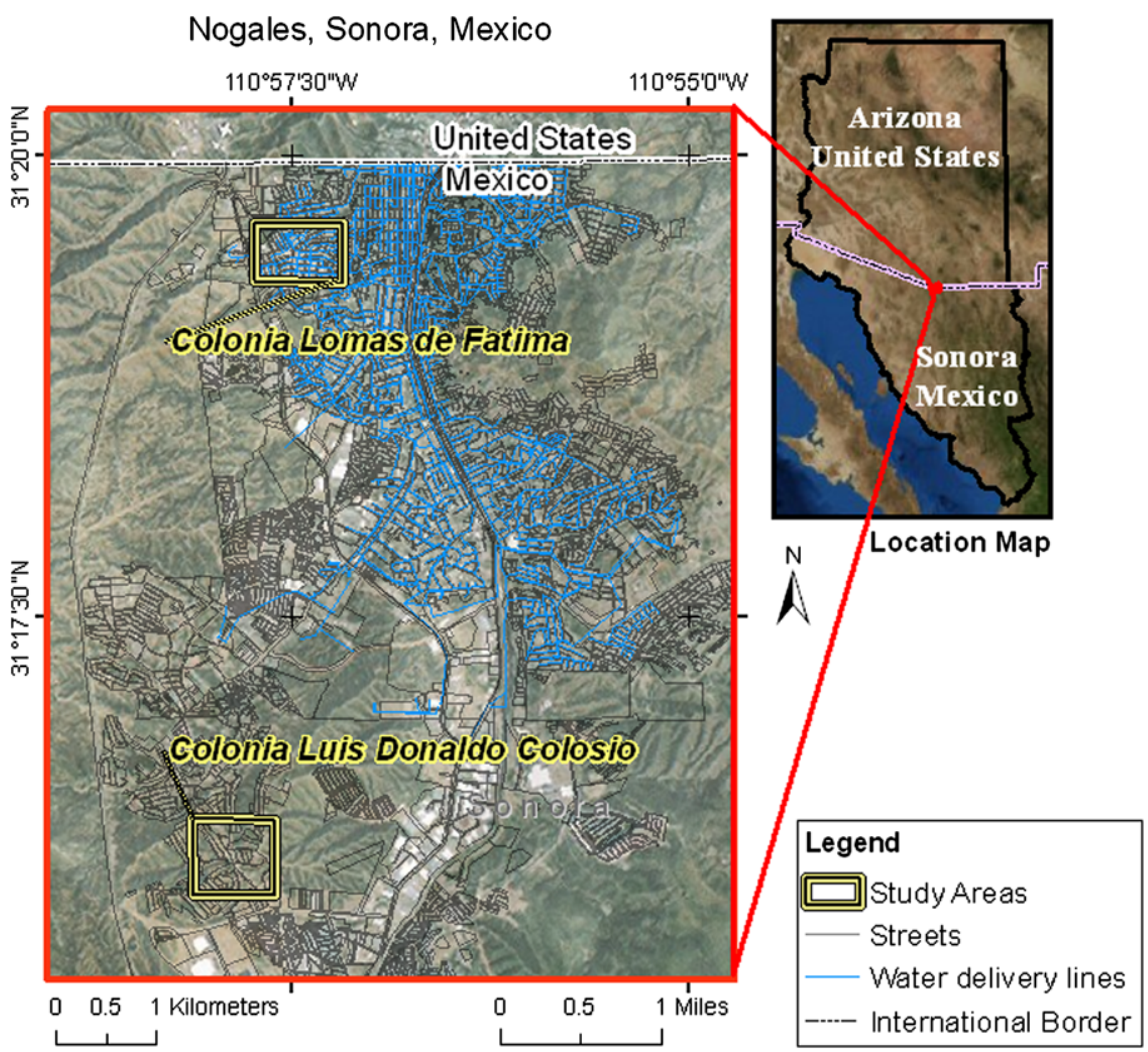

stretches about 3,000 km from the Pacific Ocean to the Gulf of Mexico and $100 \mathrm{~km}$ north and south of the line as defined by the 1983 La Paz Agreement (US Environmental Protection Agency 1983), which includes land in four American states and six Mexican states. People living in colonias, unincorporated communities that are lacking in water or wastewater infrastructure along the US-Mexico border, often face a disproportionately high level of environmental problems that are magnified by poverty, lack of education, and migratory status (Good Neighbor Environmental Board 2004; Lara-Valencia et al. 2008; Norman 2008, 2010; Norman et al. 2008, 2009, 2010a, 2012; Ramos et al. 2001). Infrastructure (i.e., potable water, sewer, pavement and availability of electricity) is poorly developed among neighborhoods (colonias marginales) distant from the established core of Nogales, Sonora, Mexico (Fig. 1; LaraValencia et al. 2008; Norman et al. 2006, 2012; Sadalla et al. 2000; Sanchez 1995). Colonias marginales are communities established in Mexico when migrant squatters settle on unoccupied land (Norman et al. 2006; Sanchez 1995; Tolan 1990). Homes are constructed using available materials, without permits, inspections, nor official recognition by the city. Public health is negatively affected by exposure of children and others to water contaminated by sewage, garbage, and occasionally industrial discharges (Ingram et al. 1994; Lara-Valencia et al. 2010; Norman 2008).

Over the past 20 years, a unique dynamic of commerce and trade has affected the region, in part due to the ratifica- tion of the North American Free Trade Agreement (NAFTA) and associated relocation of assembly plants from the United States to Mexican border towns where maquiladoras are established. The maquiladora industry contributes to environmental degradation in the Borderlands. Indirectly, the promise of employment and opportunity lure migrants from central and southern Mexico to border cities, like Nogales, Sonora, Mexico (hereafter referred to as 'Nogales'), and increased population challenges local governments to provide supporting infrastructure. Directly, maquiladoras dispose of their waste material in an unmonitored fashion (Williams 1995). Williams and Homedes (2001) identified maquiladoras as being responsible for environmental contamination and also suggest that they may contribute to changes in family cohesiveness.

Ingram et al. (1994) identified inequalities in quality, cost, and access to water-as well as inequalities of risk to human health in Ambos Nogales (both Nogales, Arizona, United States, and Nogales, Sonora, Mexico). Waterquality tests implemented by Sanchez (1995) showed the wells being used to supply water to colonias marginales in Nogales to be polluted and more expensive than betterquality water being piped to more affluent colonias. Varady and Mack (1995) conclude that poor water quality is a root cause of prevalent gastrointestinal (GI) disease in Nogales. In 2000, Sadalla et al. recognized that residents of colonias marginales in Nogales are at an increased health risk associated with poor access to clean water and inadequate water 
sanitation and storage practices which health authorities in the city associated with GI disease.

Prolonged dry periods threaten groundwater resources in the US-Mexico border, leading to the depletion of shallow aquifers (Varady and Morehouse 2004). Water scarcity compromises the ability of people living in colonias marginales to practice good sanitation (Fewtrell et al. 2007; Good Neighbor Environmental Board 2004; Norman et al. 2010b). According to Seager et al. (2007), climate models predict a drier borderlands region transitioning to an even more arid climate within a time frame of years to decades. The health implications of climate change for vulnerable populations living in colonias marginales are not good (Patz et al. 2005).

In 1990, the Council on Scientific Affairs of the American Medical Association declared that "the border area is a virtual cesspool and breeding ground for infectious diseases" (Williams 1995). Since then, a lot of attention has been placed on the impacts of maquiladoras on water quality, quality of life, and health. Binational initiatives in the areas of environmental health and water quality have successfully implemented change in the Ambos Nogales Watershed.

Research questions we identified to answer with this study include:

(1) Has there been a change in perceptions of quality of life, water quality and public health in Nogales over the past decade or two, and if so, is it comparable to other border towns?

(2) Have binational efforts of people working in Ambos Nogales improved water quality and/or decreased health risks associated with maquiladoras?

(3) Are peoples' socio-economic status continuing to define the quality of water they receive in Nogales?; and

(4) Can we identify how climate variability impacts people's everyday life, water quality, and health in Nogales?

In order to answer these questions, a study was developed to evaluate water quality for metals, chloride, sulfates, and bacteria at point of use (POU) in two neighborhoods with radically different infrastructure, to determine how water quality differs with water-delivery system and season. We identified a vulnerable colonia marginal and a prominent colonia, in Nogales to compare differences in socioeconomic classes. We developed a survey and concurrent sampling regime to determine water quality, quality of life, prevalence of diarrhea, and/or perceptions of problems and performed our investigations in the summer monsoon season and the dry winter season, to consider seasonal implications.

\section{Water in Nogales, Sonora, Mexico}

The Nogales Wash is a major tributary of the Santa Cruz River that flows directly through Ambos Nogales, draining both cities, before converging with the river near the Nogales International Wastewater Treatment Plant (NIWTP), located in Rio Rico, Arizona, 6 miles north of the border. Wastewater produced by Nogales is gravity-fed to a conveyance pipe called the International Outfall Interceptor (IOI), which delivers wastewater to the NIWTP (http://www.azdeq.gov/obep/download/wateren.pdf). The Nogales Wash flows above ground in a northerly direction in Nogales into a concrete tunnel though Nogales, Arizona, United States (hereafter referred to as 'Nogales, Arizona') that emerges into an open concrete channel and returns to a natural sediment bed channel.

During summer "monsoon" season, torrential rains commonly trigger overland flow and runoff, resulting in flash flood inundation in downtown Nogales; this sometimes causes near-surface sewerlines to break and erupt into sanitary sewer overflows, or fugas in Spanish (Huth and Tinney 2008; ADEQ 2009). Many residents in the outlying colonias marginales of Nogales use latrines or open pits for the disposal of human waste, which also regularly overflow during periods of heavy rainfall and discharge raw sewage (Austin and Trujillo 2010). Any fugitive wastewater (not captured by the sewer system) represents a threat to the public health of citizens of Ambos Nogales (Sprouse 2005). During these extreme flood events, health hazards increase from exposure to raw sewage and likely propagation and spreading of infectious disease agents (Norman et al. 2010a).

In 1990, fugas led to levels of fecal coliform and volatile organic compounds (VOCs) in the Nogales Wash inciting Santa Cruz County government to declare a health emergency (Frisvold and Osgood 2011). In the early 1990s, the Citizens' Environmental Laboratory (formerly the National Toxics Campaign) sampled waterways in several cities at the US-Mexico border, including Nogales and detected petroleum, naphthalene, total xylene, chromium, copper, and other materials (Williams 1995). In 1991, cyanide and mercury were detected at levels that exceed Environmental Protection Agency (EPA) limits (Ingram and White 1993). Varady and Mack (1995) report detections of Giardia, Cryptosporidium, parasites, petroleum, and heavy metals in the Nogales Wash. In 2000, Sadalla identified bacteriological pollution associated with deficiencies in the municipal sewerage system in Nogales-he also reported that surface-water samples in the Nogales Wash contained high levels of coliform. The International Boundary and Water Commission (IBWC) reported that portions of the Nogales Wash aquifer in Sonora were contaminated with a suspected carcinogen, tetrachloroethylene (PCE), which was also detected in border monitoring wells in Arizona (IBWC 2001; Sprouse 2005). In the Nogales Wash, at Nogales, Arizona, just downstream from Nogales, King et al. (1999) reported high levels of chromium and sediment in the water and PCBs in the fish. In 2009, ADEQ found pollutant 


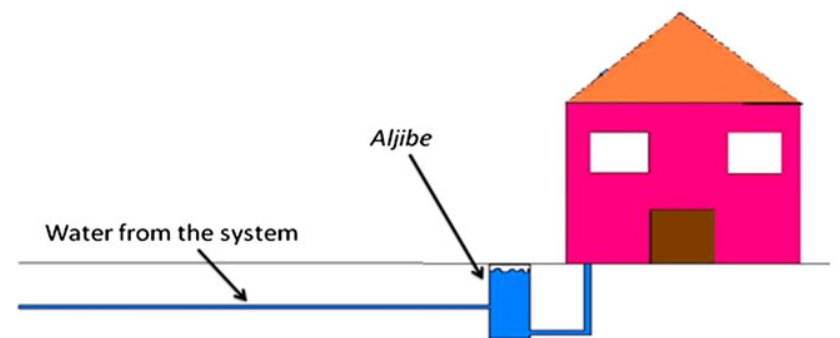

(a)

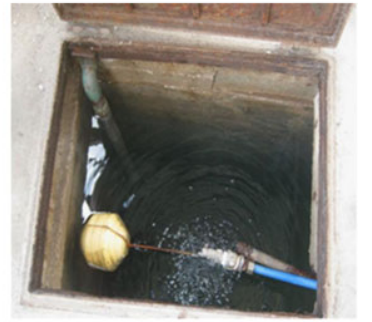

(b)

Fig. 2 (a) Diagram of aljibe and access to system and house, (b) photograph of open top aljibe in Nogales

loadings of Escherichia coli (E. coli), ammonia, chlorine, and dissolved copper to exceed surface water-quality standards in Nogales, Arizona. Chlorine is added directly to the Nogales Wash in an effort to reduce pathogens from untreated sewage entering into Arizona from Mexico, but the chlorine in the wash now exceeds Aquatic and Wildlife warm water (A\&Ww) quality standards (ADEQ 2009). In 2010, researchers from the U.S. Geological Survey's Border Environmental Health Initiative sampled surface water at five points along the upper Santa Cruz River that incorporate the same sites that King et al. (1999) had sampled, including the Nogales Wash (Norman et al. 2010b; Paretti et al. 2010). Preliminary results indicate that organic and inorganic compound concentrations increase when water is routed through Ambos Nogales, yet inorganic metals concentrations are below primary and secondary waterquality standard requirements (Paretti et al. 2010).

The surface-water/groundwater interactions in this area are largely undocumented, but contaminants have been detected in the local potable water supplies, which some people relate to leaks in sewer and water-delivery pipes (Frisvold and Osgood 2011). Researchers in the late 1980s and early 1990s found bacterial contamination, measurable amounts of the carcinogens trichloroethylene (TCE) and tetrachloroethylene (PCE), and other volatile organic compounds (VOCs) in excess of the Arizona Based Guidance Levels (ABGL) as well as maximum contaminant levels (MCL) in wells of Nogales (IBWC 2001; Varady and Mack 1995; Sanchez 1995; Tolan 1990; Williams 1987). Specific metal concentrations were not reported, but results of the 1987 ADHS analysis indicated that chromium, iron, lead, manganese, and mercury were present at several sites in unfiltered samples (Sanchez 1995).

The major aquifers have been identified as recent stream alluvium and basin fill and the groundwater flows north towards the Santa Cruz River (Arizona Department of Water Resources 2010). People living in Nogales pump water from three local well-fields: (1) from the aquifer located east of the Ambos Nogales watershed, under the Santa Cruz River; (2) from the Nogales Wash Aquifer, located underneath the city; and (3) from the Los Alisos aquifer, located 11 miles south of the city in the Rio Magdalena watershed (Sprouse 2005).

Piped water delivery in Nogales is available to established colonias from the municipal system at certain times each day, varying by location (Varady and Mack 1995). Wilder et al. (2011) identified $85 \%$ of the city as connected to a staggered water service (tandeo) across the municipality, ranging from 3 to 24 hours. The other 15 percent, who live on the edges of the city purchase water from trucks ( $p i$ pas; Ingram et al. 1994; Varady and Mack 1995).

Most residents use storage systems to ensure access to potable water at any time of day. In colonias with piped water, most homes have an aljibe. An aljibe is a cement storage tank at each home, typically located underground, which provides water to the house at a relatively constant rate (Fig. 2a). When water is available from the city system, it is delivered directly to the aljibe. During daily household use, water is pumped from the aljibe to the house and subsequently replaced by the city's intermittent water delivery. Because the aljibe is underground, the lid is at ground level and the system is subject to potential contamination from precipitation that infiltrates the tank during surface runoff events (Fig. 2b).

In colonias marginales residents purchase water from tank trucks or pipas, and usually store their purchases in plastic containers called tinacos or metal containers called tambos. Pipas are operated by the municipal water company, el Organismo Operador Municipal de Agua Potable Alcantarillado y Saneamiento-Nogales, Sonora (OOMAPASNS), and also by private owners. Publically owned pipas get water from wells that adhere to water-quality standards; while private pipa operators do not.

Tinacos (plastic water storage tanks) are purchased from home improvement stores and mounted on rooftops in colonias with wealthy residents (Ingram et al. 1994). A hose attached to the tinaco delivers water to the house by gravity (Fig. 3). Tambos (metal water storage tanks) are most often found in the less affluent colonias marginales and are usually scavenged from local industries and placed at ground 


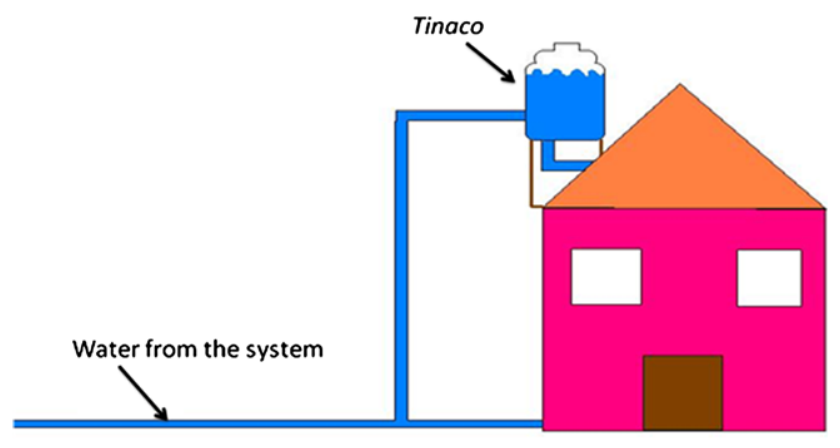

Fig. 3 Diagram of tinaco with access to system and house

level (Ingram et al. 1994). Little, if any, information about the tambo's prior contents is known by the user.

\section{Binational Cooperation}

Since the majority of these studies have been published, the population explosion has subsided (somewhat) and people have taken action. In 1993, the Border Environment Cooperation Commission (BECC) and the North American Development Bank (NADB) were created for the purpose of enhancing the environmental conditions of the US-Mexico border region and advancing the well-being of residents in both nations (Border Environment Cooperation Commission 2012). In 2000, the United States-Mexico Border Health Commission (BHC) was created to provide international leadership to optimize health and quality of life along the US-Mexico border (US-Mexico Border Health Commission 2003). In 2002, the 'Border 2012' program was established to protect the environment and public health in the US-Mexico border region, consistent with the principles of sustainable development and in 2012, this is being updated to 'Border 2020' (U.S. Environmental Protection Agency 2012a). In 2004, the USGS launched the US-Mexico Border Environmental Health Initiative (BEHI) to provide science data in support of environmental health studies and to examine and analyze linkages between human and environmental health (US Geological Survey 2012).

In border cities like Ambos Nogales, the two federal governments are working together binationally with state and local governments to improve the environmental quality and quality of life for residents. Citizen environmentalists and public servants from both sides of the border are stepping up to improve their environmental health by volunteering to sample and monitor water quality (Brown 2003), measuring rainwater and flood detention features (Norman et al. 2010b), and embracing new methods for managing waste materials (Austin and Trujillo 2010).

Current infrastructure projects are meant to reduce flooding, reduce leaks in pipes, and improve water quality, while increasing piped water delivery to colonias marginales. The NIWTP is operated and maintained by the United States Section of the IBWC, originally designed to treat 12 million gallons per day (MGD), was expanded to accommodate up to 17.2 MGD in the 1990s (King et al. 1999). In 2000, BECC certified a plan to upgrade the NIWTP to accommodate 22 MGD and build a new wastewater treatment plant in the Los Alisos basin to accommodate flows above the allotted Mexican portion of sewage (9.9 MDG) at the NITWP. The plan also called for wastewater collection systems in Ambos Nogales to be upgraded and for a conveyance system to transport the wastewater to the Los Alisos basin (Sprouse 2005). The Los Alisos Wastewater Treatment Plant and Conveyance System Construction was completed at the beginning of 2012 and expected to come online this year. With support from Border 2012, OOMAPAS-NS opened the first certified water-quality laboratory located along the Arizona-Sonora border for preliminary analysis of wastewater in 2006 (Border 2012 U.S.-Mexico Environmental Program 2008). An expansion of the water-distribution system in the city of Nogales to the colonias marginales has been approved by the BECC. This project, called the Colonia Luis Donaldo Colosio Drinking Water Distribution Expansion, would cover almost all the residents living in Colonia Flores Magon, Los Torres, Las Primaveras, Jardines de la Montana, El Rastro and Colosio, in which currently only 52 percent are serviced by the water-distribution system (U.S. Environmental Protection Agency 1999).

\section{Research Methods}

\section{Study Area}

Nogales abuts the international border and its sister-city, Nogales, Arizona (Fig. 1). Newer colonias marginales have developed and continue to develop in the hills and mountains that comprise the watershed boundary around the historic, central district of the city (Norman et al. 2006; LaraValencia et al. 2008; Wilder et al. 2011). Our experimental design involved collecting data from homes in a neighborhood with piped water and a neighborhood receiving water via pipas. Using determinations of socio-environmental vulnerability determined by Lara-Valencia et al. (2008), we chose Colonia Luis Donaldo Colosio (Colosio) to represent high vulnerability and Colonia Lomas de Fatima (Fatima) to represent low vulnerability, based on their accessibility, safety, personal contacts, and information on access to piped water (Fig. 1). We began our research by meeting with people associated with binational environmental health in Ambos Nogales (see Acknowledgments), to discuss design, implementation, cultural competency, relevancy, shared interests, and desired outcomes. This canvassing period culminated in a kick-off presentation at a binational health meeting called Consejo Binacional de Salud (COBINAS) on 
Fig. 4 Photographs of houses in (a) Colosio and (b) Fatima

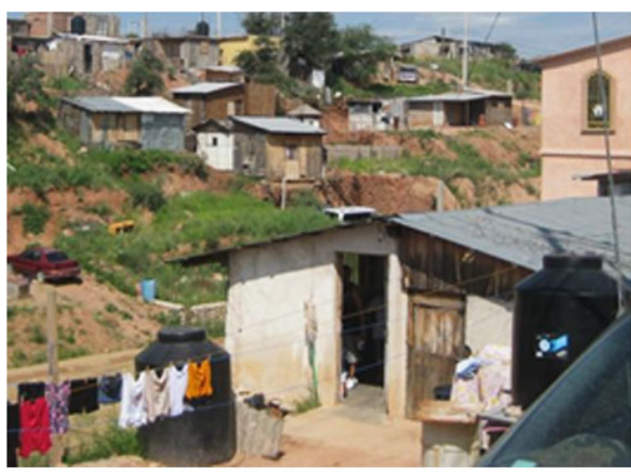

(a)

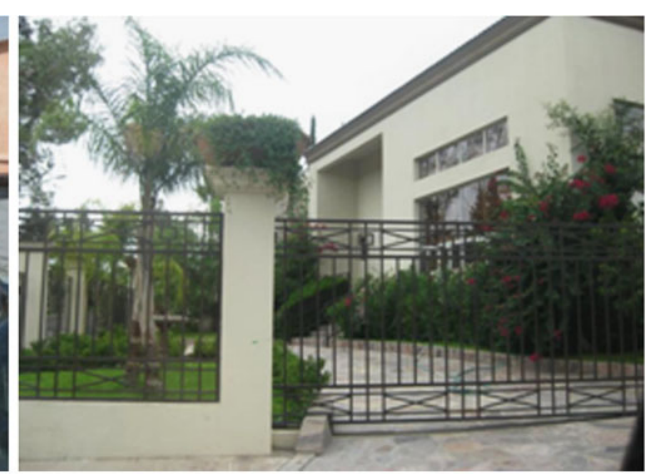

(b)
April 8, 2010, in Nogales, Arizona. The study design, neighborhood locations, and associated survey were presented and reviewed following our presentation and via e-mail correspondence by members of this group, including local physicians and promotoras, as well as city and state employees. Promotoras are community leaders who live in the colonias that have been trained to educate neighbors about government, education, and medical and social services that otherwise might be out of reach (Ramos et al. 2001; Hunter et al. 2004). Additionally, the survey describing water consumption, frequency of diarrhea, and perception of water quality was approved for the protection of human subjects (Caldeira et al. 2011).

A total of 21 households were sampled from both neighborhoods: 14 from the highly socio-environmentally vulnerable colonia (Colosio; Fig. 4a) and 7 from a more affluent and less socio-environmentally vulnerable colonia (Fatima; Fig. 4b). Unforeseen weather conditions, resources, and timing forced us to reduce our optimal 20-house sample size per colonia that was intended for the study. During the field investigations, households were chosen based on proximity to the street, with a representative from the City of Nogales, Mr. Alejandro Araiza, acting as the main liaison with residents. Interviewers asked to speak with the head of the household who was 18 years or older and then asked if the person would be willing to participate in our study.

Water samples were collected from each of the 21 households, three times in the summer during monsoon season (August 21, August 28, and September 4, 2010) and once during the winter (January 15, 2011), to test for seasonal variability. Water samples were collected from each participating household to test for microbes, and 67 inorganic chemicals. A survey was administered during the first visit in the summer (August 21,2010) and followed up again in the winter (January 15, 2011).

\section{Survey}

Using concepts of perceived risks and effects on behavior from Sadalla et al. (2000) and the investigation of ways to improve life adapted from Collins et al. (2010a), we examined the current quality of life in Nogales, where presence or absence of diarrhea was the outcome variable (Caldeira et al. 2011). Questions about how water is obtained, stored, and purified as well as rate of consumption were asked based on Sadalla et al.'s (2000) research. Quality of life questions were asked to mimic work done by Collins et al. (2010b), in terms of personal satisfaction with government resources, public infrastructure, living conditions, and the environment, on a scale from 1 to 5 , in order to investigate trends in ratings of quality of life among different income levels, as well as to illustrate perceptions of resource priority. Questions pertaining to the prevalence of diarrhea in the household, sources of water, and open-ended questions related to community involvement were created by Caldeira et al. (2011). This suite of questions was created to develop a relationship between gastrointestinal illness and water, specifically asking the respondent to answer yes or no to the following questions: did/do you or anyone in the household (i) have an episode of diarrhea in the past four weeks, (ii) get hospitalized due to diarrhea, (iii) miss work or school because of it, (iv) believe water was the cause of your sickness, and (v) think water can make you sick?

After the survey was drafted, it was revised based on feedback from stakeholder meetings. The Spanish version of the survey was translated by the authors then sent to the City of Nogales for a formal Spanish revision and cultural competency. After the final draft was completed, the survey and accompanying consent materials was sent for approval to the University of Arizona's Office for the Responsible Conduct of Research or Internal Review Board (IRB) and approval was received on July 14, 2010.

In order to recruit multiple households and administer surveys concurrently at multiple locations, student volunteers from the University of Arizona's Mel and Enid Zuckerman College of Public Health and the College of Science, and the City of Nogales were recruited and trained on the study's protocols, based on their Spanish proficiency, Human Subjects Training Certification, and willingness to help. 
The respondents from Nogales reported conditions for all members of the household. The surveys were conducted on Saturday, August 20, 2010. The average amount of time taken to complete the 30 question survey was about 35-40 minutes. In all, 21 households were represented; 14 from Colosio and 7 from Fatima. A short, five-question, follow up survey was also approved by the IRB and administered at the same participating households during the winter of 2011 (January 15, 2011) in order to test for any seasonal variability on the prevalence of diarrhea (Caldeira et al. 2011).

\section{Water Sampling}

Compliance monitoring frequently occurs at the wellhead and measures contaminant content of the water from the aquifer. Human health is most susceptible to the quality of water at the point of use (POU). Water quality at the POU reflects water quality from the well and the influence of infrastructure on water quality. In Nogales, microbiological contamination can be introduced or exacerbated by broken pipes, shallow wells within the watershed impacted by sanitary sewer overflows, insufficient chlorination, storage of water in unclean containers (aljibe, tinacos, tambos), or contamination during transport by truck.

The EPA has established National Primary Drinking Water Regulations, called maximum contaminant levels (MCLs), that set mandatory water-quality standards to protect the public against consumption of drinking water contaminants that present a risk to human health (U.S. Environmental Protection Agency 2012b).

\section{Microorganisms}

Gastrointestinal (GI) illness is caused by a variety of different microbes and germs, such as parasites, viruses, or bacteria. Testing for total coliforms is a relatively easy and inexpensive way to test for the presence of microbial pathogens. Total coliform are bacteria naturally found in the environment. Fecal coliforms are types of total coliform that mostly exist in human and animal fecal waste and E. coli is a subgroup these. Disease-causing microbes (pathogens) in feces can cause diarrhea, cramps, nausea, headaches, and more. Infants and children with their less fully develop immune systems, as well as people with severely compromised immune systems tend to be more susceptible. According to EPA MCLs, finding total coliforms (including fecal coliform and $E$. coli) exceeding zero indicate that potentially harmful bacteria (pathogens) may be present (U.S. Environmental Protection Agency 2012b).

Water samples for microbial analysis were collected from study participants' POU (i.e. kitchen faucet, tinaco, tambo, etc.) in $100 \mathrm{~mL}$ autoclaved containers to which sodium thiosulfate was added to ensure dechlorination (removal of hypochlorite anion). The samples were stored on ice until delivery for analysis at the OOMAPAS-NS water-quality laboratory. All samples were delivered to the laboratory within the 6-hour hold time. Samples were analyzed for total coliform bacteria and E. coli. Using membrane filtration, samples were incubated for 24 hours at $35{ }^{\circ} \mathrm{C}$ with m-Coliblue24®broth (Hach Company, Loveland, CO) followed by differentiation and enumeration. We collected additional, or "repeat," water samples for testing to help with quality assurance.

\section{Inorganic Chemicals}

Inorganic chemicals occur naturally in the environment, but industrial use and improper waste disposal can create conditions exceeding MCLs and threaten public health. Antimony ( $\mathrm{Sb}$ ) exceeding $0.006 \mathrm{mg} / \mathrm{L}$ can cause an increase in blood cholesterol and/or a decrease in blood sugar. Arsenic (As) exceeding $0.010 \mathrm{mg} / \mathrm{L}$ can cause skin damage, problems with circulation, and elevate cancer risk. Cadmium (Cd) exceeding $0.005 \mathrm{mg} / \mathrm{L}$ can cause kidney damage. Copper $(\mathrm{Cu})$ exceeding $1.3 \mathrm{mg} / \mathrm{L}$ can create gastrointestinal distress and/or liver or kidney damage. Lead $(\mathrm{Pb})$ exceeding $0.015 \mathrm{mg} / \mathrm{L}$ can cause delays in physical or mental development in children, and in adults, kidney problems and/or high blood pressure. Selenium (Se) exceeding $0.05 \mathrm{mg} / \mathrm{L}$ can cause hair or fingernail loss, numbness in fingers or toes, and/or other circulatory problems (U.S. Environmental Protection Agency 2012b). In addition, EPA has established National Secondary Drinking Water Regulations that set non-mandatory secondary maximum contaminant levels (SMCLs). Examples include sulfate $\left(\mathrm{SO}_{4}\right)$, which when exceeding $250 \mathrm{mg} / \mathrm{L}$ can cause diarrhea and chloride $(\mathrm{Cl})$, which when exceeding $250 \mathrm{mg} / \mathrm{L}$, can make the water taste different and in some cases can cause dehydration (U.S. Environmental Protection Agency 2012b).

Samples to be analyzed for metal and major ion concentrations were collected from the sites using a $250 \mathrm{ml}$ polypropylene bottle. The samples were filtered on-site at $0.45 \mu \mathrm{m}$ using disposable filters and $60 \mathrm{cc}$ syringes. Samples for cation analysis were collected in acid rinsed polypropylene bottles and acidified with ultra-pure $\mathrm{HNO}_{3}$. Unfiltered, unacidified subsamples for anion analysis were refrigerated until analyzed. Clean procedures were used throughout, following the protocols outlined in Ficklin and Mosier (1999). Raw samples were tested for tested Alkalinity, $\mathrm{pH}$, Conductivity, Total Dissolved Solids (TDS), and submitted for ion content analysis, including fluoride $(\mathrm{F})$, chloride $(\mathrm{Cl})$, nitrate-nitrogen $\left(\mathrm{NO}_{2}\right.$, as $\mathrm{N}$, and $\mathrm{NO}_{3}$, as $\left.\mathrm{N}\right)$, bromide $(\mathrm{Br})$, phosphorus $\left(\mathrm{PO}_{4}\right.$, as $\left.\mathrm{P}\right)$, and sulfate $\left(\mathrm{SO}_{4}\right)$.

Filtered and acidified samples were submitted for trace metal analysis. Water samples were analyzed by Activation Laboratories Ltd, Canada by inductively coupled plasma 
(ICP) atomic emission spectroscopy (AES cations), ICP mass spectrometry (MS, cations), and ion chromatography (anions). Quality assurance/quality control (QA/QC) concerns were addressed through the use of site duplicates, analytical duplicates, blanks and standards. Further descriptions of sample preparation, sample digestion, analytical methods and QA/QC protocol are found in Arbogast (1996).

\section{Results}

\section{Survey}

A total of 84 people are represented in this research, 63 from Colosio and 21 from Fatima (Caldeira et al. 2011). In regards to socio-economic status, our survey results confirmed that we had correctly selected neighborhoods from opposite ends of the socio-environmental vulnerability spectrum, none of the respondents in Colosio have water piped into their house and all respondents in Fatima have piped water. All respondents said they own their home and property rather than rent. A few residents of Colosio own a car, whereas the majority in Fatima own at least one car per household.

Caldeira et al. (2011) reported that when asked about daily consumption of water, half of households in Colosio said they drink more than eight glasses a day and the other half drank anywhere from four to six a day. In Fatima, most drank anywhere from two to six glasses of water a day with exceptions drinking more than eight. Respondents in Colosio reported that most of the water they drink is bottled and some drink water from privately owned pipas, in Fatima, the majority drink water from bottles, but some drink from the potable pipe delivered water and less from private pipas. Respondents were asked how they obtained their water for uses other activities than drinking, such as cleaning, bathing, washing, etc. and almost all respondents in Colosio said they use solely the water provided in pipas and in Fatima, almost all respondents used the piped water for purposes other than drinking.

Sadalla et al. (2000) report that $24 \%$ of residents of colonias in Nogales use cloudy or sediment-laden water purchased from trucks, $47 \%$ report consuming water directly without treatment, $37 \%$ report boiling water before consumption, and $16 \%$ report adding a disinfectant such as chlorine before consumption. According to Caldeira et al. (2011), little has changed. A majority of respondents in both Colosio and Fatima said that water reaching the home is clear, while the remainder report sediment in the water. Most respondents said they store their water in some way. A majority of respondents in Colosio said they store their water either in a tinaco or a tambo. In Fatima, all respondents store their water in tinacos and or in aljibes. Almost none of the respondents in Colosio treat their water before using it but in Fatima, half disinfect their water using chlorine or some other method. The majority of respondents in both Colosio and Fatima said they paid about the same amount of money (100-500 Mexican pesos or 10-50 US dollars) each month for water expenses in spite of the differing delivery mechanisms and quality of delivered water.

In Collins et al. (2010b) implemented a survey along several US-Mexico border towns (not including Nogales) with results indicating the majority of people living in border towns in Mexico, are happy with their water and quality of life and unconcerned with the impact of water quality on their health. This holds mostly true for residents that were interviewed in Nogales as well (Caldeira et al. 2011). Respondents in Colosio were indifferent to the overall purity of potable water in Nogales, and all respondents in Fatima rated the purity of water as above average. In regard to quality of life, the majority of respondents in Colosio rated their satisfaction with 'personal quality of life', as very satisfied, but in Fatima, only half said they were very satisfied with their quality of life. However, the majority of respondents in both Colosio and Fatima said they were very happy, in general, with their life in Nogales.

Concerning public health and GI illness, of the 21 households recruited for this study in the summer months, ten households reported a case of diarrhea within the four weeks prior to the survey. Of those ten households, six were from Colosio and four were from Fatima indicating that the rate of diarrhea in both colonias was nearly $50 \%$. The rate of requiring specialized treatment for diarrhea is higher in Colosio than in Fatima. No household in either colonia reported an episode of diarrhea within one week from when the follow up survey was implemented during the winter.

The rate of diarrhea was low during the winter months, which suggests that heat and/or heavy precipitation related to monsoons might be associated with GI illness. When asked what they believe caused their episode of diarrhea, no household blamed the consumption of water, but some households claimed it was the heat and climate that caused their episode of diarrhea. In terms of climatic challenges that affect water resources such as flooding and drought, almost half of respondents in both Fatima and Colosio said they are not concerned at all. A more detailed account of the survey process, with itemized questions and results are available in Caldeira et al. (2011).

\section{Microorganisms}

In the summer, seventy-nine percent of homes in Colosio had E. coli present, and in winter, $43 \%$ did, whereas we detected no E. coli in Fatima in either season (Fig. 5). In Colosio, we detected total coliform bacteria at every home in the summer and at $57 \%$ of homes in the winter. In Fatima, only $57 \%$ were positive for total coliform bacteria in the summer and $14 \%$ in the winter. 
Table 1 Mean, median, and standard deviation of selected metal and ion concentrations collected on 8/21/2010

\begin{tabular}{|c|c|c|c|c|c|c|c|c|c|c|c|c|}
\hline & \multicolumn{3}{|c|}{ Arsenic (As) $\mathrm{mg} / \mathrm{L}$} & \multicolumn{3}{|c|}{ Cadmium (Cd) mg/L } & \multicolumn{3}{|c|}{ Chloride (Cl) $\mathrm{mg} / \mathrm{L}$} & \multicolumn{3}{|c|}{ Copper (Cu) mg/L } \\
\hline & Mean & Median & Std Dev & Mean & Median & Std Dev & Mean & Median & Std Dev & Mean & Median & Std Dev \\
\hline Colosio & 0.00143 & 0.00064 & 0.00135 & 0.000185 & 0.000065 & 0.000331 & 24.6 & 29.2 & 12.8 & 0.0241 & 0.0054 & 0.0457 \\
\hline Lomas & 0.00541 & 0.00368 & 0.00354 & 0.000073 & 0.000055 & 0.000049 & 9.1 & 7.7 & 3.4 & 0.0660 & & 0.0790 \\
\hline \multirow[t]{3}{*}{ Both } & 0.00298 & 0.00305 & 0.00307 & 0.000142 & 0.000060 & 0.000264 & 18.6 & 10.0 & 12.7 & 0.0402 & 0.0100 & 0.0627 \\
\hline & \multicolumn{3}{|c|}{ Manganese (Mn) mg/L } & \multicolumn{3}{|c|}{ Molyebdenum (Mo) mg/L } & \multicolumn{3}{|c|}{ Lead $(\mathrm{Pb}) \mathrm{mg} / \mathrm{L}$} & \multicolumn{3}{|c|}{ Antimony (Sb) mg/L } \\
\hline & Mean & Median & Std Dev & Mean & Median & Std Dev & Mean & Median & Std Dev & Mean & Median & Std Dev \\
\hline Colosio & 0.00302 & 0.00265 & 0.00234 & 0.00083 & 0.00085 & 0.00034 & 0.000543 & 0.000350 & 0.000683 & 0.000138 & 0.000110 & 0.000080 \\
\hline \begin{tabular}{|l|} 
Lomas \\
\end{tabular} & 0.00222 & & & & & & 0.000897 & 0.001050 & & 0.000303 & 0.000330 & 0.000101 \\
\hline \multirow[t]{3}{*}{ Both } & 0.00271 & 0.00235 & 0.00221 & 0.00112 & 0.00100 & 0.00062 & 0.000679 & 0.000455 & 0.000631 & 0.000201 & 0.000160 & 0.0 \\
\hline & \multicolumn{3}{|c|}{ Selenium (Se) mg/L } & \multicolumn{3}{|c|}{$\operatorname{Tin}(S n) \mathrm{mg} / \mathrm{L}$} & \multicolumn{3}{|c|}{ Sulfate (SO4) mg/L } & \multicolumn{3}{|c|}{$\operatorname{Zinc}(Z n) \mathrm{mg} / \mathrm{L}$} \\
\hline & Mean & & & & & & Mean & & & & & Dev \\
\hline Colosio & 0.00044 & 0.00040 & 0.00021 & 0.0187 & 0.0177 & 0.0166 & 36.7 & 45.9 & 24.6 & 0.0438 & 263 & 0.0516 \\
\hline Lomas & 0.00138 & 0.00170 & & & & & 28.7 & & & & & 0.0171 \\
\hline Both & 0.00080 & 0.00060 & 0.00058 & 0.0196 & 0.0169 & 0.0186 & 33.7 & 36.5 & 20.7 & 0.0452 & 0.0342 & 0.0413 \\
\hline
\end{tabular}

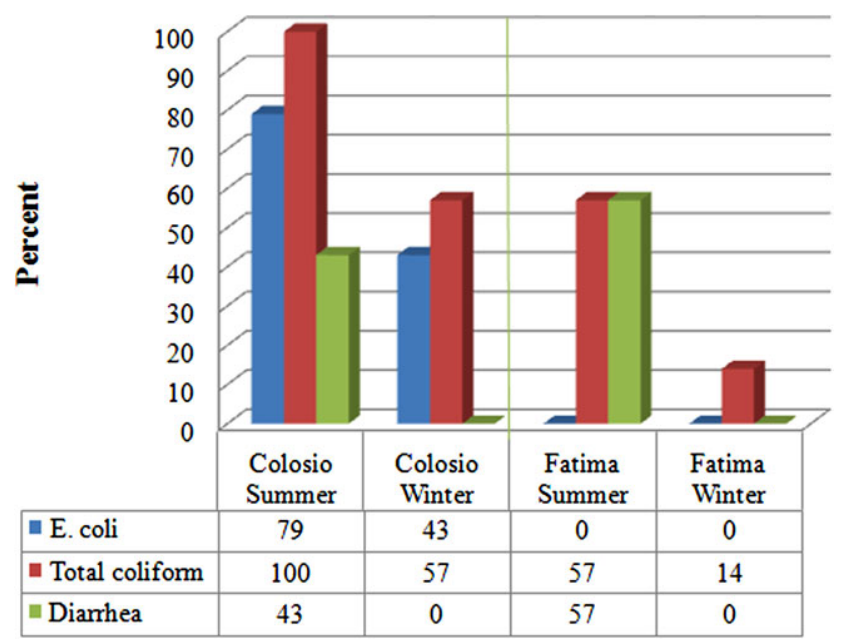

Fig. 5 Graph depicting the frequency of homes positive for $E$. coli and total coliform bacteria in comparison with reported case of GI illness for summer and winter samples

Inorganic Chemicals

Unlike reports we have cited from the 1990s, all water samples tested were well below the US EPA's maximum contaminant level (MCL) in both colonias for inorganic chemicals. We selected inorganic chemicals described already in this paper that have potential health effects associated with long-term exposure and that might be associated with both population and industrial growth to report in Table 1, including arsenic (As), cadmium $(\mathrm{Cd})$, chloride $(\mathrm{Cl})$, copper $(\mathrm{Cu})$, manganese $(\mathrm{Mn})$, molybdenum $(\mathrm{Mo})$, lead $(\mathrm{Pb})$, antimony $(\mathrm{Sb})$, selenium $(\mathrm{Se})$, tin $(\mathrm{Sn})$, sulfate $\left(\mathrm{SO}_{4}\right)$, and zinc $(\mathrm{Zn})$.

Natural sources of inorganic compounds include erosion and runoff of natural deposits ( $\left.\mathrm{As}, \mathrm{Pb}, \mathrm{Cd}, \mathrm{Se}, \mathrm{SO}_{4}\right)$, as well as orchards (As). Anthropogenic sources include petroleum refineries (As, Se, Cd), fire retardants (PBDEs), ceramics (multiple metals $\mathrm{Pb}, \mathrm{Co}, \mathrm{Cu}$ ), electronics ( $\mathrm{Au}, \mathrm{Ag}$ ), solder $(\mathrm{Pb})$, corroded household plumbing systems (As, $\mathrm{Pb}, \mathrm{Cd}$ ), discharge from mines $(\mathrm{Au}, \mathrm{Ag}, \mathrm{Cu}, \mathrm{Se})$, runoff from waste batteries of paints $(\mathrm{Cd})$, and/or glass and electronic production wastes (As; U.S. Environmental Protection Agency 2012b). It is noted that EPA has established a public health goal for water concentrations not to exceed $0 \mathrm{mg} / \mathrm{L}$ for metals such as Arsenic and Lead.

\section{Discussion}

As Collins et al. (2010a) stated, there is a common misconception by outsiders that quality of life in Mexico is low, yet people living in Nogales report being generally happy and satisfied. We discovered that the two colonias varied not only by economic status and water-delivery system, but by perceived health risk associated with water quality and personal behavior.

Microbial contamination is high, particularly in the marginalized colonia, Colosio, which lacks access to piped water. Observations are similar to those found by earlier researchers (Varady and Mack 1995; Sanchez 1995; Williams 1987) who sampled wells. However for this project water was obtained from the household's reported point of use (i.e. kitchen faucets running from tinacos and or aljibes or standalone tinacos and tambos). Sanchez (1995) stated that no microbial contamination was observed in water sampled from the municipal water system, but there is no mention of which locations in the municipal water system were sampled (i.e. point of use, pipas, distribution site, treatment plant, city pipes, etc.). Since we found microbial contamination in excess of the US EPA's recommended MCL of $0 \mathrm{mg} / \mathrm{L}$ for majority of the households in Colosio, water is contaminated at levels that are unsafe at the point at which it 
reaches the user. Intermediate points of contamination could be aljibes, tambos or tinacos because water from the municipal system reaches these containers prior to entering the home. Most residents indicated that the only disinfection practice they use is chlorine treatment, without mention of sanitizing their storage containers when empty. Research volunteers also observed numerous water containers without lids which could lead to environmental exposure. Despite the fact that Fatima receives municipally treated piped water, we detected coliform bacteria in these homes, possibly indicating that there is an intermediate route of contamination that impacts the municipal water supply as it is delivered to the home. Alternatively, homes could have leaking pipes or lack back flow valves that might be sources of contamination.

There was marked seasonality of E. coli and total coliform concentrations in Nogales (Fig. 5). The average E. coli count in Colosio dropped from 26.7 (summer) to 3.7 colonies per $100 \mathrm{~mL}$ (winter). Total coliform bacteria were similarly reduced from 79.4 in the summer to 65.8 average colonies $/ 100 \mathrm{~mL}$ during winter in the Colosio neighborhood. Mann-Whitney U tests indicate that $E$. coli and total coliform concentrations, between neighborhoods, differed significantly in both summer and winter seasons $(p=0.05)$. The decline in reported diarrhea from summer to winter was far greater in the Fatima neighborhood than in the Colosio but neither neighborhood reported diarrhea in the winter.

The rate of diarrhea is high during the summer as reported through interviews with individual residents of households, yet diarrhea occurrence appears independent of water quality. Our hypothesis was that Fatima residents would not report elevated GI illness during the summer because homes in Fatima receive piped water, but this was not the case. Although they differ in magnitude, diarrhea rates in both colonias are high and compromise health. This suggests that the occurrence of diarrhea or perceived occurrence may be independent of water quality alone and therefore other confounding factors, independent of the water system, may play a role in the subject's overall health profile during the summer months. In Colosio, residents use latrines with limited containment of human waste, and runoff from heavy rainfall can transport waste and excrement throughout the city. Fecal-laden runoff can contaminate improperly sealed aljibes. As conditions dry the resulting dust can contaminate tinacos and tambos via wind transport. These pathways of contaminant transport are potential causes of the elevated levels of microbes found during the summer season in Nogales. Elevations in temperature and humidity, found in Nogales during the summer, increase the survival rate of bacteria (Maier et al. 2009). The cooler temperatures of winter may limit survival of bacteria on surfaces. It is also possible that summer exposures to unrefrigerated food, dust containing feces, and hand to mouth contact from contaminated surfaces are potential hazards that might not be as great during winter conditions when indoor environments may be cooler and drier. The increase in microbial contamination during the rainy summer season may likely be caused by heavy runoff (Curriero et al. 2001). Curriero et al. (2001) discovered that there was a statistically significant association between rainfall and waterborne disease outbreaks between 1948 and 1994 due to surface-water contamination from extreme precipitation. This information has serious public health implications since the region has experienced an increase in extreme weather recently (including both drought and rainfall-flooding events) attributable to climate change (Lara-Valencia et al. 2010; Morehouse et al. 2000; Norman et al. 2010a). Seasonal differences in these exposures, in addition to water exposures, may account for elevated diarrhea rates during the summer and the non-occurrence of diarrhea during the winter months in Nogales.

Chloride in water may be an indicator of naturally present salt in the environment or may indicate exposure to anthropogenic sources such as inorganic fertilizers, landfill leachates, septic tank effluents, animal feeds, industrial effluents, irrigation drainage and chlorine treatment (World Health Organization 2003). Because residents in Colosio have their water storage containers exposed to the environment and report treating with chlorine (Caldeira et al. 2011), elevated levels of chloride are expected (World Health Organization 1979).

In addition to climate, factors such as insufficient chlorination, food preparation and contamination, medication, prior illnesses, and hygiene may contribute to GI problems. Numerous reports illustrate the impact that social equity has on accessing clean piped water and the increased risk of illness and mortality to less privileged individuals (Aldous 2003; Colford et al. 2006; Chiller et al. 2006; Esrey et al. 1990; Ezzati et al. 2005; US-Mexico Border Health Commission 2003). According to our results, people living in more affluent areas of Nogales have less E. coli and less total coliform in their water than the more vulnerable populations, yet percent-wise, report more cases of diarrhea. It is important to point out that calculation for this research is dependent on a low sample size, and in Fatima are based on only 7 households, so a difference of only one household could drastically change percentages.

Metal concentrations were well below the US EPA's MCL, unlike research in the past (Varady and Mack 1995; Sanchez 1995; Williams 1987). Sanchez (1995) stated that contaminants found in well water within the watershed were traced to industries in the area. The recent attention to environmental health and waste disposal may have indirectly and directly played a part in the improved quality of the water. 


\section{Conclusion}

This study investigates health as it pertains to gastrointestinal disease by using qualitative and quantitative methods in two neighborhoods in Nogales, by implementing a survey that inquires about quality of life, water delivery, rate of diarrhea, and disinfection practices, as well as chemically analyzing water from POU. Previous work in Nogales did not investigate the direct effect of water quality on health and water-quality samples were obtained from wells rather than from POU. A successful collaboration of people from both sides of the border, including researchers, local epidemiologists, directors of public health agencies, health care professionals, directors of zoning and planning, local water technicians, and government officials, worked together to develop and shape the study, to make it useful for stakeholders.

To improve future surveys, we hope to increase sample size and representation of additional colonias. Collection of samples during four seasons over multiple years would provide a more complete picture of seasonal variability. It would be advantageous to collect water samples from every point within the distribution system (i.e. well, treatment facility, pipa, city pipe line, tinaco/tambo/aljibe) to better identify sources of contamination. A comparison of the neighborhoods in Nogales, Arizona, would complement this research greatly. Due to time constraints, weather, and limited resources, sample size was reduced from the original study design. Although limited in scope, we strongly believe the results provide researchers and stakeholders with a status report regarding potential concerns and issues and add to the literature on environmentally related risk perceptions in the Borderlands.

It has been documented that people living along the US-Mexico border are subject to environmental injustice because of the mixed cultures, administrative authorities, clashing priorities, and distance from each country's capital. Policies that have been developed to allow international trade foster economic incentive that has little regard for impacts on the health and quality of life for borderland residents. However, the people who live in the borderland region have been working together to change the way they live. Recent collaboration in binational environmental and watershed management has brought about changes in lifestyle and infrastructure in Nogales, Sonora, Mexico, and its sister-city, Nogales, Arizona, United States, that is improving environmental health and quality of life for the people.

Acknowledgements This research was developed and supported by the U.S. Geological Survey (USGS) U.S.-Mexico Border Environmental Health Initiative (BEHI) and Geographic Analysis and Monitoring Program (GAM). We acknowledge Alejandro Araiza from the City of Nogales, Sonora (el Ayuntamiento de Nogales Sonora); staff from the Nogales, Sonora Municipal Operating Agency for Water and Wastewater (el Organismo Operador Municipal de Agua Potable Alcantarillado y Saneamiento; OOMAPAS-NS); Sofia Grigera, and
Ashley Riggs from the USGS; Perry Gast and Luis Lozano from the University of Arizona (UA) Mel and Enid Zuckerman College of Public Health (MEZCOPH); Claudia Gil from Municipal Institute for Research and Planning (Instituto Municipal de Investigación y Planeación; IMIP); and Jesús Quintanar from the Mexico Section of the International Boundary and Water Commission (la Comisión Internacional de Limites y Aguas; CILA) for the time and energy they contributed to this effort. Any use of trade, firm, or product names is for descriptive purposes only and does not imply endorsement by the U.S. Government.

Other invaluable stakeholders who helped direct our research include associates from the Binational Health Council for Ambos Nogales (Consejo Binacional de Salud de Ambos Nogales; COBINAS); Drs. Jose Salvador Mercado Guitierrez, Esther Solis, and Vladimir Canchola Cecena from the Center for Urban Health in Nogales ( $\mathrm{el} \mathrm{Cen-}$ tro de Salud Urbano en Nogales; $C S U$ ); Selma Valenzuela and Francisco Octavio Gastelum from OOMAPAS-NS; Myrna Seiter, Robert Guerrero, and Sarah White from the Arizona Department of Health Services (ADHS); Leonor Sesteaga from the Association of Promoters of Health for Nogales (Asociación de Promotoras de Nogales; APN); associates from the U.S.-Mexico Border 2012 Arizona/Sonora Children's Environmental Health Task Force; Edna Mendoza and Jose Rodriguez from the Arizona Department of Environmental Quality (ADEQ); Christina Araiza from Esperanca Inc.; Blanca Andrade from the Mariposa Community Health Center; Jill de Zapien and Dr. Cecilia Rosales from the UA MEZCOPH; Francisco Lara-Valencia from Arizona State University (ASU) School of Transborder Studies; Laura López Hoffman, Jeremy Slack, Margaret Wilder, and Robert Varady from the UA Udall Center for Public Policy Studies; and Charles van Riper, Justan Bell, Logan Matti, and Miguel Villarreal from the USGS. The authors wish to acknowledge the U.S. Environmental Protection Agency's (EPA) Ecosystem Services Research Program (ESRP) for their interest in this research. Finally, the authors would like to especially thank Nicholas Paretti (USGS) and Hans Huth (ADEQ) for their help and careful reviews of this manuscript.

\section{References}

Aldous P (2003) The world's forgotten crisis. Nature 422:251

Arbogast BF (1996) Analytical methods manual for the Mineral Resource Surveys Program. U.S. Geological Survey Open-File Report 96-525

Arizona Department of Environmental Quality (2009) Nogales wash total maximum daily load. Arizona Department of Environmental Quality

Arizona Department of Water Resources (2010) Santa Cruz active management area (AMA). In: Arizona water atlas. Active management area planning area, vol 8, pp 316-355

Austin D, Trujillo F (2010) Composting toilets and water harvesting: alternatives for conserving and protecting water in Nogales, Sonora. U.S. Environmental Protection Agency Through the Border Environment Cooperation Commission

Border 2012 U.S.-Mexico Environmental Program (2008) Improving water quality in Arizona-Sonora. http://www.azdeq.gov/obep/ download/wateren.pdf. Accessed 7 Feb 2012

Border Environment Cooperation Commission (2012) BECC and NADB; successful bi-national cooperation. http://www.becc.org/ english/index.html. Accessed 7 Feb 2012

Brans EHP (1997) The scarcity of water: emerging legal and policy responses. Kluwer Law International, Alphen aan den Rijn

Brown C (2003) New directions in binational water resource management in the U.S.-Mexico borderlands. Soc Sci J 40:555-572. doi:10.1016/S0362-3319(03)00068-5 
Caldeira F, O’Rourke MK, Gil C (2011) Water and wellness in two colonias of Nogales, Sonora, Mexico. Int J Health Wellness Soc $1: 193-212$

Chiller TM, Mendoza CE, Lopez MB, et al (2006) Reducing diarrhea in Guatemalan children: randomized controlled trail of flocculent-disinfectant for drinking water. Bull World Health Organ 84(1):28-35

Colford JM Jr, Roy S, Beach MJ, et al (2006) A review of household drinking water intervention trials and an approach to the estimation of endemic waterborne gastroenteritis in the United States. J Water Health 4:71-88

Collins K, Guhathakurta S, Pijawka D, et al (2010a) The border observatory: assessment of perceptual and objective quality of life indicators in the U.S.-Mexican border. Southwest Consortium for Environmental Research \& Policy

Collins K, Guhathakurta S, Sadalla E, et al (2010b) A longitudinal assessment of quality of life in the US-Mexico border region. 73

Curriero FC, Patz JA, Rose JB, Lele S (2001) The association between extreme precipitation and waterborne disease outbreaks in the United States, 1948-1994. Am J Publ Health 91:1194-1199. doi:10.2105/AJPH.91.8.1194

Esrey SA, Potash JB, Roberts L, et al (1990) Health benefits from improvements in water supply and sanitation; survey and analysis of the literature on selected diseases. Wash technical report

Ezzati M, Utzinger J, Cairncross S, et al (2005) Environmental risks in the developing world: exposure indicators for evaluating interventions, programmes, and policies. J Epidemiol Community Health 59:15-22

Fewtrell L, Prüss-Üstün A, Bos R, et al (2007) Water, sanitation and hygiene: quantifying the health impact at national and local levels in countries with incomplete water supply and sanitation coverage. World Health Organization, Geneva

Ficklin W, Mosier E (1999) Field methods for sampling and analysis of environmental samples for unstable and selected stable constituents. The environmental geochemistry of mineral deposits. Society of Economic Geologists Part A, 249-264

Frisvold G, Osgood DE (2011) Financing wastewater collection and treatment on the US-Mexico border. J Contemp Water Res Educ 121:7

Good Neighbor Environmental Board (2004). Children's environmental health: spotlight on the U.S.-Mexico border

Hunter JB, de Zapien JG, Papenfuss M, et al (2004) The impact of a promotora on increasing routine chronic disease prevention among women aged 40 and older at the U.S.Mexico border. Health Educ Behav 31:18S-28S. doi:10.1177/ 1090198104266004

Huth H, Tinney C (2008) Causes and consequences of monsoonal flooding in Nogales, Sonora. In: Proceedings of a USGS workshop on facing tomorrow's challenges along the US-Mexico border-monitoring, modeling, and forecasting change within the Arizona-Sonora transboundary watersheds. U.S. Geological Survey Circular, vol 1322, pp 49-52

Ingram H, White DR (1993) International boundary and water commission: an institutional mismatch for resolving transboundary water problems. Nat Resour J 33:153

Ingram H, Milich L, Varady RG (1994) Managing transboundary resources: lessons from Ambos Nogales. Environ Sci Policy Sustain Dev 36:6-38. doi:10.1080/00139157.1994.9929996

International Boundary and Water Commission (2001) Final report of the binational Nogales Wash United States/Mexico groundwater monitoring program

King K, Zaun B, Velasco A (1999) Contaminants as a limiting factor of fish and wildlife populations in the Santa Cruz River, Arizona. US Fish Wildl Serv Reg 2:57

Lara-Valencia F, Declet-Barreto J, Keys E (2008) Spatial equity and transportation hazard along cross-border trade corridors: the case of Ambos Nogales. J Biopharm Stat 23:1-18
Lara-Valencia F, Brazel AJ, Mahoney E, et al (2010) The response of US-Mexico border cities to climate change: current practices and urgent needs. Southwest Consortium for Environmental Research and Policy

Maier RM, Pepper IL, Gerba CP (2009) Environmental microbiology. Academic Press, San Diego

Morehouse BJ, Carter RH, Sprouse TW (2000) Implications of sustained drought for transboundary water management in Nogales, Arizona, and Nogales, Sonora. Nat Resour J 40:783

Morua AR, Halvorsen KE, Mayer AS (2011) Waterborne diseaserelated risk perceptions in the Sonora River Basin, Mexico. Risk Anal 31:866-878. doi:10.1111/j.1539-6924.2010.01570.x

Norman LM (2008) Urbanization and environmental health in Arizona Colonias. In: Donelson AJ, Esparza AX (eds) The colonias reader: economy, housing, and public health in U.S.-Mexico border colonias. University of Arizona Press, Tucson, pp 204-217

Norman LM (2010) United States-Mexican border watershed assessment: modeling nonpoint source pollution in Ambos Nogales. J Biopharm Stat 22:79-97

Norman LM, Donelson A, Pfeifer E, Lam AH (2006) Colonia development and land use change in Ambos Nogales, United StatesMexican border. US Geological Survey Open-File Report 20061112:121

Norman LM, Hirsch DD, Ward AW (2008) In: Proceedings of a USGS workshop on facing tomorrow's challenges along the U.S.Mexico border-monitoring, modeling and forecasting change within the Arizona-Sonora transboundary watersheds

Norman LM, Feller M, Guertin DP (2009) Forecasts of cross-border urban growth using the SLEUTH model; Ambos Nogales watershed, United States-Mexican border. Comput Environ Urban Syst 33:150-159

Norman LM, Callegary J, van Riper C, Gray F (2010a) The border environmental health initiative; investigating the transboundary Santa Cruz watershed. US Geological Survey Fact Sheet 20103097:2

Norman LM, Huth H, Levick L, et al (2010b) Flood hazard awareness and hydrologic modelling at Ambos Nogales, United States-Mexico border. J Flood Risk Manag 3:151-165. doi:10.1111/j.1753-318X.2010.01066.x

Norman LM, Villarreal ML, Lara-Valencia F, et al (2012) Mapping socio-environmentally vulnerable populations access and exposure to ecosystem services at the U.S.-Mexico borderlands. Appl. Geogr. 34:413-424. doi:10.1016/j.apgeog.2012.01.006

Paretti N, Callegary J, Gray F, Beisner K, Norman L, Van Riper C (2010) Occurrence, fate, and bioaccumulation of organic and inorganic contaminants from multiple sources in the Upper Santa Cruz watershed, [abs.], Arizona Hydrological Society, Sept 1-4. Tucson, Arizona

Patz JA, Campbell-Lendrum D, Holloway T, et al (2005) Impact of regional climate change on human health. Nature 438:310-317

Ramos IN, May M, Ramos KS (2001) Environmental health training of promotoras in colonias along the Texas-Mexico border. Am J Publ Health 91:568

Sadalla E, Swanson T, Velasco J (2000) Residential behavior and environmental hazards in Arizona-Sonora colonias. SCERP project No. EH-98-2 http://www.scerp.org

Sanchez RA (1995) Water quality problems in Nogales, Sonora. Environ Health Perspect 103:93-97

Seager R, Ting M, Held I, et al (2007) Model projections of an imminent transition to a more arid climate in Southwestern North America. Science 316:1181-1184. doi:10.1126/science.1139601

Sprouse TW (2005) Water issues on the Arizona-Mexico border. Water Resources Research Center, College of Agriculture and Life Sciences, University of Arizona, Tucson, AZ, USA

Tolan S (1990) Hope and heartbreak: the border boom. New York Times Magazine 1 
US Environmental Protection Agency (1983) Agreement for the protection and improvement of the environment in the border area. http://www.epa.gov/border2012/docs/LaPazAgreement.pdf. Accessed 7 Feb 2012

US Environmental Protection Agency (1999) Environmental assessment for water system improvements; city of Nogales, Sonora, Mexico. http://www.epa.gov/usmexicoborder/ infrastructure/nogales/water.html. Accessed 7 Feb 2012

US Environmental Protection Agency (2012a) US-Mexico border 2012. http://www.epa.gov/usmexicoborder/. Accessed 7 Feb 2012

US Environmental Protection Agency (2012b) Drinking water contaminants I drinking water contaminants. http://water.epa.gov/drink/ contaminants/index.cfm. Accessed 7 Feb 2012

US Geological Survey (2012) U.S.-Mexico border environmental health initiative. http://borderhealth.cr.usgs.gov. Accessed 7 Feb 2012

US-Mexico Border Health Commission (2003) Healthy border 2010 an agenda for improving health on the United States-Mexico border. http://www.borderhealth.org. Accessed 7 Feb 2012
Varady RG, Mack MD (1995) Transboundary water resources and public health in the US-Mexico border region. J Environ Health 57:8

Varady R, Morehouse BJ (2004) Issues and context. In: The social costs of industrial growth in Northern Mexico, vol 22, p 205

Wilder M, Slack J, Garfin GM, et al (2011) Urban water vulnerability and institutional challenges in Ambos Nogales. 50

Williams JD (1987) Groundwater sampling plan for Nogales Wash. Arizona Department of Health Services

Williams EJ (1995) The maquiladora industry and environmental degradation in the United States-Mexican borderlands

Williams DM, Homedes N (2001) The impact of the maquiladoras on health and health policy along the U.S.-Mexico border. J Public Health Policy 22:320-337. doi:10.2307/3343145

World Health Organization (1979) Sodium, chlorides, and conductivity in drinking water: a report on a WHO working group. Copenhagen

World Health Organization (2003) Chloride in drinking-water; background document for development; WHO guidelines for drinkingwater quality. Switzerland 